\title{
AN ANALYSIS OF POLITENESS PRINCIPLE IN THE BADUNG REGENT CANDIDATES DEBATE IN 2015
}

\author{
Md. Aryasih', N. Adi Jaya Putra², I.G. Budasi ${ }^{3}$ \\ ${ }^{123}$ English Language Education, Post Graduate Program, Universitas Pendidikan Ganesha, Singaraja \\ e-mail: madearyasih22@gmail.com, jaya.putra@pasca.undiksha.ac.id, gede.budasi@pasca.undiksha.ac.id
}

This study aimed at: 1) finding maxims of politeness principle expressed in Badung Regent Candidates Debate in 2015; 2) finding the most dominant maxim of politeness principle used in Badung Regent Candidates Debate in 2015. This study was designed mainly as a descriptive qualitative study which then supported by some descriptive quantification. The objects of the study were the utterances containing maxims of politeness principle expressed by the regent and vice regent candidates of Badung in Badung Regent Candidates Debate in 2015. The data were analyzed based on the theory of politeness principle proposed by Leech and the theory of categorization of speech act by Searle. The results of the study display that there are six maxims of politeness principle expressed in Badung Regent Candidates Debate in 2015 , namely the tact maxim, the generosity maxim, the approbation maxim, the modest maxim, the agreement maxim and the sympathy maxim. Furthermore, it is found out that the generosity maxim is the most dominant maxim used by the regent and vice regent candidates in Badung Regent Candidates Debate in 2015. The generosity maxim expressed in the debate applied the commissive type of speech act. Through the utterances of this maxim, they intend to convince the audience that they attempt to minimize benefit to self and maximize cost to self. The maxims expressed by the regent and vice regent candidates in the debate have a goal to communicate effectively

\section{Keywords: political debate, politeness principle, maxim, speech act}

\section{INTRODUCTION}

A leader should be a trustworthy person. This is one requirement that should be fulfilled by a person who wants to be a leader, a leader of any fields or institutions. Thus, the requirement is also applied for a leader of a country or a region. Trustworthiness has been becoming a crucial issue in a country or regional leadership history in the world. Many countries which are previously powerful can become in ruin due to misleading policy direction from their leaders. It has been recorded through history that some powerful countries have been degraded into powerless countries after an era of certain leaders reigning, such as Soviet Union, German, and Greece. Indonesia as a big developing country also has ever experienced a misleading era. This had triggered the reformation of the nation in 1998. At that time, Indonesian people did not believe the leader of the country- the president. Trustworthiness that they sought after a leader could not be found in the president figure. As a public figure, he failed to prove his credibility as corruptions happened in many fields of bureaucrat in this country. As a public figure, he failed to prove his credibility as corruptions happened in many fields of bureaucrat in this country. People could not see trustworthiness in him that made him replaced by a new leader- a new president. Thus, trustworthiness as the base of credibility of a leader has been a point of interest of people throughout the world as well as Indonesia. People learn from history that they should be more cautious in electing a leader that they desire, a trustworthy leader.

The need to find a trustworthy leader of a nation or a region has urged the emergence of political debate in an election. In a campaign of the pre- election, political debates are held. A political debate can be referred to as a political discussion which has opposing arguments from the participants. In a political debate, a moderator will raise the topics. The participants then express their ideas concerned with the topic and argue with other participants to defend their points of view. In this kind of debate, a moderator will allocate the time for the participants to speak. Political debates are mainly aimed to show people about their vision and mission that they will do when they rule a region. Thus, political debates can be used as an important instrument to measure the capacity and capability of leaders candidate in 
modern democracy. Through the debate, people know whether the candidates really comprehend problems that their countries or their regions have. Furthermore, through the debate, people will view the candidates' readiness to solve problems that arise in their country or region.

The political debates held are believed to increase the public' preference of the electability of the region leaders candidates. This fact is found in the survey carried out by Kompas survey and research department in the $28^{\text {th }}$ of January to $4^{\text {th }}$ February 2017 (Akbar, 2017 ). One of the indicator is the increasing debate viewers. There are $57.6 \%$ viewers from 804 respondents admit that they watch the debate of the first Jakarta leader candidates election. The number of the viewers increase at the second debate. It becomes $62.2 \%$. The findings of the survey also show that $28.4 \%$ respondents admit that they are sure to change their choice after watching the debate. The finding has proved that the debate has a significant effect on the election of the leader candidates.

Political debates can be used as a tool to impress their viewers through language that they speak and how they express it. The choice of the language and the way they convey it in expressing their ideas and intention seem to influence the success of the debate. Moreover, the tensity of the debate atmosphere often has effects on the performance of the participants of the debate. Due to this, it is often found out that the participants of the debate cannot control themselves and respond using inappropriate language or even express their intention in impolite ways. This phenomenon has made the writer of the study interested in analyzing the language the debaters used in relation with politeness.

People tend to have expressions of politeness to achieve their goal in a communication. Through politeness utterances, people try to express their intention to make other people understand what they mean. To accomplish this intention is not always easy. Sometimes, people cannot feel satisfied with the result of their communication. Pertinent to this, people needs to know what expressions of politeness that they should utter when they communicate. The right choice of expressions of politeness can lead participants in a conversation achieve success in a communication.

Expressions of politeness are concerned with pragmatics which is a study about how to produce and understand language in communication. This will be clarified in the following definitions of Pragmatics. According to Thomas (1995), pragmatics includes the following considerations, that are : (1) meaning which is negotiated in the expression delivered from speaker to listener, (2) the context of the expression produced, and (3) the potencies of meaning contained in an expression. This definition seems to have a quite similar definition stated by Yule (1996). He said that pragmatics is a study which focuses on the meaning of the expression stated by a speaker which suits a listener's interpretation. Then, Yule stated that pragmatics has four definitions, such as: (1) The study which is concerned with the meaning of speaker's expression, (2) The study of meaning of an expression related to the context of situation , (3) the study of how expression can become more communicative than it is stated, and (4) The study of how expression delivered based on the distance in relationship (distant or close) between the speaker and the listener.

It is stated by Thomas (1995) that pragmatics is regarded to meaning of expression which is negotiated by speaker and listener, this is aligned with what has been stated by Leech about pragmatics. Leech (1983) states that problem solving is included in pragmatics with regard to speaker's and hearer's perspectives. From speaker's perspective, planning is the problem. Whereas, interpretation is the problem from hearer's perspective.

Words can have specific meaning in specific situations. It is simply can be stated that Pragmatics is a study of language which is concerned with interpreting words in various ways pertinent to context of the situation.

H. Paul Grice proposed Cooperative Principle (CP) in 1975. According to Grice, conversation occurs due to this principle, i.e., a shared principle of cooperation. It is stated as make a required conversational contribution suitable with the context of situation, i. e., the setting - place, time, participants- involve in a conversation. Related to this, Thomas (1995) has an opinion that this principle has an idea that people who involve in a conversation accept that it has certain rules operated, except if they get contrary indications. CP is elaborated in four conversational maxim, such as maxim of quantity, maxim of quality, maxim 
of relation and maxim of manner. Maxim of quantity set the following requirements, that are, (a) Make the contribution as informative as is required for the current purpose of the exchange, (b) Do not make our contribution more informative than is required. It means that number of utterances used to deliver message must be informative as what is required and it is not more or less than that. The maxim of quality applies two rules, namely (a) Do not say what you believe to be false and (b) Do not say that for which you lack adequate evidence. The message which is delivered must be true and it does not lack of suitable evidence. The rule operated in the maxim of relation is being relevant. Relevant is meant to the connection of the speaker's expression and the addressee's respond are relevant to each other. The example of the maxim of relation can be seen in the following expressions. There are four rules conducted in the maxim of manner, such as : (a) obscurity of expression must be avoided, (b) ambiguity has to be avoided, (c)it has to be brief (unnecessary prolixity has to be avoided), and (d) it has to be orderly. It means utterance that is expressed must be clear. It must have clear text and clear message. Cleat text is constructed by syntax and phonology of the language. Then, clear message is when the sense of illocutionary goal expressed is understandable.

The first theory of Politeness Principles is invented by Robin Lakoff in 1973. In Lakof's opinion, politeness can be defined as interpersonal relation systems to facilitate interactions by minimizing the potential for conflict and confrontation inherent in all human interchange (Lakoff in Karafoti, 2007). According to Lakoff, politeness are forms of behavior that have been developed in societies in order to reduce friction in personal interaction. In her Politeness Principle, she proposed that politeness consists of three things, namely Don't impose or Distance, Give Option or Deference and lastly Make Audience Feel Good or Camaraderie.

Politeness is viewed by lde as an attempt which aims to maintain communication run smoothly. She has an opinion that politeness is a constraint which exists when people interact to each other to avoid friction (Ide, 1993). It is then concerned with strategies of use of language and choice of forms of language which are related to maintain a communication run smoothly. According to Ide, politeness consists of two parts, namely violation and discernment. Violation is concerned with the choice of strategies employed by speakers regarding language utterances. The strategies include maxim which is delivered by a speaker to express polite language which aims at causing good feeling for the hearer. Whereas, discernment as the other element of politeness is concerned with the ability of speakers to recognize the right type of behavior (Fauziati, 2013).

Blum-Kulka describes the features of politeness, such as something which is external, a hypocritical thing, and a non -natural thing. Her description of politeness is related to the politeness' perspective as an outward mask. According to Blum-Kulka, politeness is a kind of insincere performance which has a goal to perform good manners. It maybe also be expressed to obtain a certain thing which is completely different from the meaning of the expression of politeness stated (Blum-Kulka in Fauziati, 2013).

From the three politeness theories, it can be seen that politeness principle deals with good manners, how speakers express their intention to make hearers feel good. To realizing this idea, i.e., to make hearers feel good, speakers should know what politeness expression that they can utter in a conversation. This idea is related to Watt's statement. He states that humans are not born with politeness. However, they have to gain knowledge of politeness and then are immersed into it. Furthermore, he states that there has been no generation who has resources of polite skill acquisition from teachers as well as books of etiquette on correct behavior (Watts, 2003).

Pragmatics as a branch in linguistics which studies of meaning in interaction encompasses some principles in communication as well as Politeness Principle. Geoffrey Leech (1983) introduced Politeness Principle (PP) in communication. In Leech's opinion, politeness is concerned with a relationship between two participants which are called self and other. In speech event, the speaker will be the identification of self and hearer will be the identification of the other. Furthermore, Leech has a view that politeness can be displayed by the speaker to the third parties, who may or may not attend the speech event. PP has an idea of producing and understanding expressions which are concerned with politeness. 
Creating the sense of community and social relationship are the goal of PP. According to Leech, the general formulation of PP in its negative form is minimizing impolite beliefs expressions and maximizing polite beliefs expressions which is considered less important, in which that is the corresponding positive version.

Leech further states that polite and impolite beliefs expressions are favourable and unfavorable beliefs to the hearer or to a third party in which relevant scales of values can be used to measure favourable and unfavourable beliefs. Leech also views that PP is applied for social equilibrium and the friendly relations maintenance which can make us have an assumption that at first our interlocuters are cooperative (Leech, 1983).

A number of maxims dealing with polite behavior are defined as maxims of politeness principle (Leech, 1983). Politeness principle proposed by Leech has six maxims which facilitate to elaborate relationship between sense and force in everyday speech event.

The tact maxim is applied to minimize cost to other and to maximize benefit to other. The tact maxim applies to Searle's directives and commissives speech act, which requires to perform some action either by the hearer or the speaker. Commissives deal with expressions which show speaker's intention to do action in the future. Whereas, the directives are concerned with utterances that affect the action which is done by the hearer. The generosity maxim is expressed to minimize benefit to self and maximize cost to self. The generosity maxim can be found in commissives and directives speech act. This maxim is centered to self. On the other hand, the tact maxim is focused to other. The approbation maxim expressed has an intention to minimize dispraise of other and maximize praise of other. In this maxim, saying unpleasant things about others and especially about the hearer is avoided. The approbation maxim exists in assertives and expressives Searle's category of speech act. Assertives contain expressions which show the true propositional. Whereas, expressive are utterances which display the feeling of the speaker. The modesty maxim expressed is aimed at minimizing praise of self and maximizing dispraise of self. This maxim can be found in assertive and expressive illocutionary act. The degree of good or bad evaluation of other or self expressed by the speaker becomes the concern of the modesty maxim. This type of maxim usually occurs in apologies. The agreement maxim stated has an aim to maximize agreement between self and other and minimize disagreement between self and other. In the agreement maxim, disagreement is uttered through regret or partial agreement. The agreement maxim is applied in in assertives speech act. The sympathy maxim expressed is intended to maximize sympathy between self and other and to minimize antipathy between self and other. Expressions of congratulation on the achievement of other people occur in the sympathy maxim. On the other hand, sympathy or condolences are expressed when people experience calamity.

Leech's maxims of politeness principle has a pragmatic scale. Based on the scale, we can determine the degree of politeness contained in an expression of a certain maxim. The Cost-Benefit Scale is used to estimate the cost or benefit of the action offered to speaker or hearer (Leech, 1983). The orientation of the scale is to the hearer or the addressee. If the cost is higher than the benefit of the hearer, the expressions are regarded as less polite. Whereas, if the benefit is higher than the cost of the hearer, the expressions are considered more polite. It means that the expressions which contain higher cost to the hearer demonstrate the less of politeness. Whereas, the greater of politeness occurs in the expressions which give the higher benefit to the hearer. The optionality scale displays the order of illocutions which is based on the number of choice allowed by speaker to hearer (Leech, 1983) An option or choice usually can be found in a request or command which are expressed in indirect utterance. When the speaker's request or command gives options or choices to the hearer for the responses, they are believed to increase the politeness' degree. The indirectness scale is based on the order of illocutions which is related to the length of the path (in terms of means-end analysis) relating the illocutionary act to its illocutionary goal (Leech, 1983). The use of indirect illocutions determines the degree of politeness. The higher indirectness of an illocution, the higher the degree of politeness it has. In other words, indirect utterance is considered more polite. The authority scale is a scale pertinent to social status relationship between speaker and hearer. The utterance that the speaker expressed can reveal the hearer's social status, whether the hearer has superior, subordinate or equal social 
status with the speaker. It often occurs that speakers with higher social status have authority to command hearers with lower social status. The social distance scale is a scale which considers the degree of familiarity between speaker and hearer. This is used to display the deference, the existence, or the solidarity between the speaker and the hearer. It can be said that the more familiar the speaker and the hearer, they will show the higher solidarity. On the contrary, the less familiar the speaker and the hearer, or the more distant the relationship between them, they will display the lower solidarity.

Politeness affects Searle's classification of speech act or it is referred to illocutionary act by Leech. Leech's maxims of politeness principle apply to Searle's speech acts categories. There is an assumption which bases the theory of speech act in which it states that a sentence or other expression is not the minimal unit of human communication, but rather the performance of certain kinds of acts, such as making statements, asking questions, giving orders, describing, explaining, apologizing, thanking, etc (Searle, in Al Malik, 1995). He further states that it is important to study speech act. In Searle's opinion, involving a linguistic act is necessary to any specimen of linguistic communication (Searle, 1969). The speech acts categorized by Searle are elaborated in the following section :

1. Assertives commit speaker to the truth of the expressed proposition: e.g., stating, suggesting, boasting, complaining, claiming, reporting (Leech, 1983:105).

2. Directives are intended to produce some effect through action by the hearer: ordering, commanding, requesting, advising, and recommending are examples (Leech, 1983: 106).

3. Commissives commit speaker (to a greater or a lesser degree) to some future actions; e.g., promising, vowing, offering (Leech, 1983:106).

4. Expressives have the function of expressing, or making known, the speaker's psychological attitude towards a state of affairs which the illocution presupposes; e.g., thanking, congratulating, pardoning, blaming, praising, condoling,etc (Leech, 1983:106).

Regarding the influence of maxims of politeness principle to Searle's categories of illocutionary act, it can be stated that a certain maxim applies to certain Searle's category of speech act. The tact maxim applies to directives and commissive speech act as well as the generosity maxim. Whereas, the approbation and the modesty maxim apply to Searle's expressive and assertive illocutionary act. Finally, the agreement and sympathy maxim apply to Searle's assertive type of illocutionary act.

Regarding the political debate and the politeness principle, the writer was interested to conduct this study to analyze the utterances of politeness expressed by the regent and vice regent candidates of Badung in Badung Regent Candidates Debate in 2015. It is interesting to know whether the participants of the debate use expressions of politeness to impress the audience in the debate with their ideas and concerns in which this will lead them to be elected as the leaders of Badung Regency. Being the leaders of Badung Regency is an important and prestigious status, as this regency has been the focus of attention in Bali. This is due to its highest regional income which has the biggest contribution to help the development in Bali. This region has also contributed its income to help the development of some regencies in Bali.

This study has objectives to find the maxims of politeness principle expressed in Badung Regent Candidates Debate in 2015 and to find the most dominant maxim of politeness principle used in Badung Regent Candidates Debate in 2015.

\section{RESEARCH METHOD}

This research is mainly a qualitative research which then supported by some descriptive quantification. In this study, the researcher collected the data which was in form of video document of Badung Regent Candidates Debate in 2015.The debate was broadcasted by TVRI Bali, Bali Tv and Dewata Tv Source of the data was the discourse uttered by the four candidates of regent and vice regent in Badung Regent Candidates Debate in 2015. The discourse were then transcribed by the writer of this study. In this study, every expressions uttered by the regent and vice regent candidates containing maxims of politeness principles were analyzed based on the theory of politeness principle proposed by Leech and theory of 
speech acts categorization by Searle. Then, the writer of this study attempted to find out the most dominant maxim of politeness principle used by the four candidates of regent and vice regent of Badung in the debate. The subjects of this study are four regent and vice regent candidates of Badung Regency in ruling year of 2016 -2021.. In this study, the researcher also needed some supporting instruments, such as the flashdisk, laptop, and earphone.

\section{FINDINGS AND DISCUSSION}

There are six maxims of politeness principle proposed by Leech in the expressions of the regent and vice regent candidates in the debate, namely Tact Maxim (TM), Generosity Maxim (GM), Approbation Maxim (AM), Modesty Maxim (MM), Agreement Maxim (AgM), and Sympathy Maxim (SM).

The occurrence of the maxims of politeness principles in Badung Regent Candidates Debate in 2015 is presented in the following table.

Table 1. The Occurrence of Maxims Of Politeness Principle

\begin{tabular}{ccccccc}
\hline $\begin{array}{c}\text { Subjects Of } \\
\text { The Study }\end{array}$ & $\begin{array}{c}\text { Tact } \\
\text { Maxim }\end{array}$ & $\begin{array}{c}\text { Generosity } \\
\text { Maxim }\end{array}$ & $\begin{array}{c}\text { Approbation } \\
\text { Maxim }\end{array}$ & $\begin{array}{c}\text { Modesty } \\
\text { Maxim }\end{array}$ & $\begin{array}{c}\text { Agreement } \\
\text { Maxim }\end{array}$ & $\begin{array}{c}\text { Sympathy } \\
\text { Maxim }\end{array}$ \\
\hline RC1 & 2 & 3 & 0 & 0 & 4 & 0 \\
VRC1 & 2 & 3 & 0 & 1 & 2 & 0 \\
RC2 & 0 & 6 & 3 & 1 & 1 & 1 \\
VRC2 & 0 & 5 & 0 & 0 & 1 & 0 \\
Total & 4 & 17 & 3 & 2 & 8 & 1 \\
\hline
\end{tabular}

Table 1 displays the number of data of the occurrence of Maxims of Politeness Principle in the Badung Regent Candidates Debate in 2015. The findings show that six maxims of politeness principle expressed by the regent and vice regent candidates of Badung Regency, namely the Tact Maxim, the Generosity Maxim, the Approbation Maxim, the Modesty Maxim, the Agreement Maxim, and the Sympathy Maxim. There are thirty five data of utterances which contain maxims of politeness principle in the debate. The table also shows that the most dominant maxim of politeness principle used by the regent and vice regent candidates in the debate is the Generosity Maxim. There are seventeen data of utterances of the Generosity Maxim. All the participants of the Badung Regent Candidates Debate in 2015 employed the Generosity Maxim. Whereas, not all the participants of the debate expressed the Tact Maxim, Approbation Maxim, Modesty Maxim, and Sympathy Maxim. This fact can be seen through the number of the occurrence which is written zero. The percentage of the occurrence of the maxims of politeness principles delivered by the regent and vice regent candidates in debate is presented in the table below.

Table 2. The Frequency of Occurrence of Maxims Of Politeness Principles In The Debate

\begin{tabular}{clc}
\hline No. & \multicolumn{1}{c}{$\begin{array}{c}\text { Maxims Of Politeness } \\
\text { Principles }\end{array}$} & Frequency (\%) \\
\hline 1. & Tact Maxim & $11.43 \%$ \\
2 & Generosity Maxim & $48.57 \%$ \\
3 & Approbation Maxim & $8.57 \%$ \\
4 & Modesty Maxim & $5.71 \%$ \\
5 & Agreement Maxim & $22.86 \%$ \\
6 & Sympathy Maxim & $2.8 \%$ \\
& TOTAL & $100 \%$ \\
\hline
\end{tabular}


Table 2 displays the frequency of all six maxims of politeness principles expressed by the regent and vice regent candidates in Badung Regent Candidates Debate in 2015. The most dominant or the most frequent maxim delivered by the participants is the Generosity Maxim. It is $11.43 \%$. Then, the Agreement Maxim is less expressed by the participants in the debate. It is $22.86 \%$. The Tact Maxim has lesser frequency than the Agreement Maxim. It is $11.43 \%$. The least expressed maxim of politeness principles is the Sympathy Maxim. It is only $2.8 \%$.

The findings display that the six maxims of Politeness Principle proposed by Leech expressed by the regent and vice regent candidates of Badung in Badung Regent Candidates Debate in 2015. The participants of the debate employed the six maxims of politeness principle, namely the Tact Maxim, the Generosity Maxim, the Approbation Maxim, the Modesty Maxim, the Agreement Maxim and the Sympathy Maxim.

The Tact Maxim is expressed to minimize cost to other and maximize benefit to other. This maxim also occurred in the debate. Based on the cost benefit scale proposed by Leech, in tact maxim, the speaker tried to be more polite by maximizing benefit to other. Through their utterances, they tend to do some actions in the future which give maximum benefit to other, i.e. people in Badung Regency. Through this maxim, the speakers attempt to show that they will become leaders who will give benefits for the regency, such as they refuse reclamation for Teluk Benoa and will do things that benefit their people and the synergy that they will do, will be worthwhile not only for Badung Regency but also for Bali. The participants of the debate employed the Tact Maxim which applies to Searle's commissive type of illocutionary act. They use act of offering and promising. The Generosity Maxim is stated to minimize benefit to self and maximize cost to self. The generosity maxim is contained in commissive speech act, proposed by Searle. In the debate, the regent and vice regent candidates use commissive speech act, such as promising and offering. The participants in 2015 Badung Regent Candidates Debate expressed the generosity maxim of politeness principle more frequent than the other maxims of politeness principle. Based on the cost benefit scale proposed by Leech, in the expressions which contain the generosity maxim, the speakers have an attempt to be more polite by maximizing cost to self. Commissive speech act is found in the generosity maxims expressed by the regent and vice regent candidates in Badung Regent Candidates Debate in 2015. They expressed it through promise and guarantee. Based on the findings of the research carried out in this study and the previous studies conducted by the other researchers, it can be seen that participants of political debate in pre-election campaign, tend to express guarantee and promise. They choose using those speech acts to convince the audience. The Approbation Maxim can also be found in the debate. The Approbation Maxim is uttered to minimize dispraise of other and maximize praise of other to avoid saying unpleasant things. The Approbation Maxim expressed by the participants in the debate applies to Searle's expressive illocutionary act. The regent and vice regent candidates delivered praising act. The participant compliments the development in Badung Regency. He says that it is amazing. The speaker also says a pleasant thing about job opportunity in Badung Regency which is still wide open for the job seekers. The Modesty Maxim employed by the regent and vice regent candidates in the debate has lower frequency than the Approbation Maxim. This maxim is expressed to minimize praise of self and maximize dispraise of self. The Modesty Maxim delivered by the participants applies to Searle's expressive type of illocutionary act. They use act of praising in the modesty maxim. The speakers praise the authority of Bali Province Government. The speaker will ask permission from the Governor of Bali before communicating with the society. The occurrence of the Agreement Maxim is less than the Generosity Maxim. This maxim is expressed to minimize disagreement between self and other and to maximizeagreement between self and other. The Agreement Maxim expressed by the regent and vice regent candidates in the debate applies to Searle's assertive type of speech act. The act of stating is used by the participants in uttering the maxim. The statements that contain this maxim are expressed by the speakers to show that they are in agreement with the government of Badung Regency and the panelists in the debate about certain good things which have been adopted and applied by the government and the society, such as law enforcement and the adoption of Tri Hita Karana philosophy which are believed to create balance in developing Badung Regency. The data show that the least stated maxim in the debate is Sympathy Maxim. This maxim is employed by the speaker to maximize sympathy between self and other and minimize 
antipathy between self and other. The Sympathy Maxim expressed in the debate applies to Searle's assertive type of illocutionary act. The speaker uses the act of complaining. The speaker feels sorry about the reclamation of Teluk Benoa which disadvantages the environment as well as the society.

\section{CONCLUSION AND SUGGESTIONS}

Regarding to the results of the study, it can be concluded that there are six maxims of Politeness Principles proposed by Leech expressed by the regent and vice regent candidates of Badung in Badung Regent Candidates Debate in 2015, namely the Tact Maxim, the Generosity Maxim, the Approbation Maxim, the Modesty Maxim, the Agreement Maxim, and the Sympathy Maxim. The maxims of politeness principle expressed by the participants in the debate have a goal to communicate effectively. The expressions of maxim of politeness principles serve to suit the needs of the participants to achieve what they desire in the debate. So, they can achieve success in communication which will lead them to be voted in the Badung Regent Election. The most dominant maxim used by the participants in the debate is the Generosity Maxim. Through the utterances of this maxim they intend to convince the audience that they attempt to minimize benefit to self and maximize cost to self. The regent and vice regent candidates show their generosity by expressing their willingness to do actions which maximize cost to self. Through the expression of the Generosity Maxim, they try to assure the people in Badung Regency that they are worthy to be elected as the regent and vice regent of Badung.

Based on the conclusion, the writer of this study would like to give some suggestions, such as this study can be used as a reference for other researchers who wish to conduct study about maxims of politeness in conversation, especially in a debate. Moreover, they should also analyze the data based on other maxims proposed by other linguists to make a deeper comprehending study. There should be more studies analyzing speech acts contained in maxims of politeness to give an overview for linguists who then enlighten people to be more effective in communication and to be more successful. Through the right choice of expressing speech acts, they can achieve their goal in communicating their ideas.

\section{ACKNOWLEDGEMENT}

The writer's gratitude goes to several parties. First and foremost, the rector, the director of post graduate program and the head of English post graduate program of Ganesha University of Education who facilitated her to accomplish this research. Second, KPU Badung for giving permission to collect the data for this research and the writer supervisors.

\section{REFERENCES}

Akbar, Jay. 2017. "Benarkah Debat Pilkada Mempengaruhi Elektabilitas?" Retrieved from https://tirto.id > Politik

Alvaro, Ramiro.N. 2011. The Role of Conversational Maxims, Implicature and Presupposition in the Creation of Humour: An Analysis of Woody Allen's Anything Else. Master Dissertation. UCM. Retrieved from https://eprints.ucm.es , MA_Dissertation_Ramiro_Nieto_(2011)

Al-Bantany,N.F. (2013). The Use of Commissive Speech Acts and Its Politeness Implication - A Case of Banten Gubernatorial Candidate Debate. Retrieved from ejournal.upi.edu/index.php/psg/article/download/534/409

Al Malik, Fahad M. 1995. Performative utterances : their basic and secondary meanings with reference to five English translations of the meanings of the Holy Qur'an. Thesis. Durham University. Retrieved from [PDF] The Translation - Durham e-Theses - Durham University etheses.dur.ac.uk >

Candrawati, Putu. 2009. Discourse Analysis of Conversational Maxims on a Debate of Governor and Vice Governor Candidates of Bali in Ruling Year 2008-2013. Undergraduate Thesis (Unpublished). Singaraja : Universitas Pendidikan Ganesha

Creswell, John W. 2012. Educational Research Planning, Conducting, and Evaluating 


\section{Quantitave and Qualitative Research. Boston: Pearson Education, Inc.}

Fergina, Ana. "Analysing Utterances on Movie by Using the Gricean Maxim". Retrieved fromhttps://media.neliti.com > media > publications > 218109-analysing-utterance...

Faridah, 2016. Flouting Conversational Maxim Used by Main Characters in Lie to Me Movie. Undergraduate Thesis. Retrieved from [PDF] Flouting Conversational Maxim Used by Main etheses.uin-malang.ac.id > ...

Fauziati, Endang. 2013. "Linguistic Politeness Theory". Retrieved from https://publikasiilmiah.ums.ac.id > bitstream > handle > 4_LINGUISTIC PO

Grice, H. P. 1975. "Logic and Conversation". In P. Cole and J. Morgan (eds) Studies in Syntax and Semantics III: Speech Acts, New York: Academic Press, pp. 183-98. Retrieved from Grice's Cooperative Principle

https://www.lancaster.ac.uk > fass > projects > stylistics > topic12

Hales, David. An Introduction to Triangulation.UNAIDS Monitoring and Evaluation Fundamentals. Retrieved from https://www.unaids.org > files , files > 10_4-Intro-totriangulation-MEF

Hidayati, F., Indarti, Y. 2013. "An Analysis of the Violation of Maxims In Malam Minggu Miko Situation Comedy ".Retrieved from [PDF] An Analysis of the Violation of Maxims in Malam Minggu Miko journal.unair.ac.id > .

Ide, Sachiko. 1993. "Preface The Search for Integrated Universal of Linguistic Politeness". Retrieved from www.sachikoide.com , 1993_Preface_The_Search_for_Integrated_Univer...

Karafoti, Eleni. 2007."Politeness, gender and the face of the speaker".Aristotle University of Thessaloniki. Retrieved from https://www.researchgate.net, publication, 237136969 Politeness gender

Kheirabadi, R.2012. "Grice's Cooperative Maxims as Linguistic Criteria for News". Retrieved from www.academypublication.com > issues > past > tpls > vol02

Leech, Geoffrey N. 1983. Principles of Pragmatics. New York: Longman, Inc.

Levinson, Stephen C. 2000. Pragmatics. Australia: Cambridge University Press.

Loof,J. 2018. Gricean Maxims in the TV Series The Office. An analysis of the character Dwight regarding failure to observe Gricean maxims. Retrieved from www.divaportal.org > smash > get > diva2:1251455 > FULLTEXT0

Mardani,A. An Analysis of Obama's Speech Acts on the Third Presidential Debate in the United States Presidential Election 2012.2012. Retrieved from www.academia.edu/.../AN ANALYSIS OBAMA S SPEE

Nugraha, R.A. 2013. Maxim Violation in Real Steel Movie : A Pragmatic Approach. Undergarduate Thesis. Surakarta : Universitas Muhamadiyah Surakarta. Retrieved from [PDF] Maxim Violation in Real Steel Movie : A Pragmatics eprints.ums.ac.id , Naskah_Publikasi

Nurdianingsih, Eka. 2006. An Analysis of Tact and Approbation Maxims Based on Leech's Politeness Principles in the Movie "Maid in Manhattan". Undergraduate Thesis. Surakarta : Universitas Sebelas Maret. Retrieved from [PDF]An analysis of tact and approbation maxims based on leech's..

https://digilib.uns.ac.id/...=/An-analysis-of-tact-an...

Robihun, Wahyu. 2009. A Politeness Maxims Analysis on the Dialogue of the American's Presidential Candidates Debate. Undergraduate Thesis. Universitas Islam Negeri Syarif Hidayatullah Jakarta. Retrieved from repository.uinjkt.ac.id , dspace , bitstream , WAHYU ROBIHUN-FAH

Sari, Dhesta. M. 2013. A Socio-Pragmatic Analysis of Politeness Strategies Performed by 
Barack Obama And Hillary Clinton in the Democratic Debate Held on February 26, 2008. Undergraduate Thesis. Yogyakarta : Yogyakarta State University Retrieved from eprints.uny.ac.id/.../Dhesta\%20Maydiana\%20Sari...

Searle,J. (1969). What is a Speech Act? Retrieved fromhttps://faculty.unlv.edu/jwood/unlv

Taufik,K.S. The Persuasive Utterances in a Political Discourse (The Case Study of the Regent Election Campaign of Pasuruan, East Java-Indonesia). 2014. Retrieved from www.macrothink.org/journal/index.php/ij//article/viewFile/.../pdf_

Thomas, Jenny. 2013. Meaning in Interaction: an Introduction to Pragmatics. London: Routledge Retrieved from Meaning in Interaction | An Introduction to Pragmatics Taylor ...https://www.taylorfrancis.com > books

Watts, Richard J. 2003. Politeness. New York : Cambridge University Press.

Yule, George. 1996. Pragmatics. Oxford: Oxford University Press. Retrieved fromPragmatics by George Yule.pdf - Google Docshttps://docs.google.com s viewer 